\title{
Effect of Organic Content on Anaerobic Biodegradability by Agricultural Waste Biomass
}

\author{
Kook-Sik Shin ${ }^{1}$, Young-Man Yoon ${ }^{2}$, and Yeon-Kyu Sonn ${ }^{1}$ * \\ ${ }^{1}$ National Academy of Agricultural Science, RDA, Suwon 441-707, Republic of Korea \\ ${ }^{2}$ Biogas Research Center, Hankyong National University, Anseong, 456-749, Republic of Korea
}

(Received: March 4 2014, Accepted: May 23 2014)

\begin{abstract}
Recently interest on production of biogas from biomass resources has increased because of climate change in worldwide. In this study, anaerobic digestion efficiency of 17 different types of agricultural waste was evaluated using biochemical methane production potential estimated from the Intemational biochemical methane potential standard method (Germany VDI4630). As a result, theoretical biochemical methane potential $\left(B_{\text {th }}\right)$ of agricultural waste biomass ranged from 0.266 to $0.488 \mathrm{Nm}^{3} \mathrm{~kg}^{-1}$-Volatile Solid (VS) added. Ultimate biochemical methane potential $\quad\left(B_{u}\right)$ of agricultural waste biomass ranged between 0.176 and 0.417 $\mathrm{Nm}^{3} \mathrm{~kg}^{-1}-\mathrm{VS}_{\text {added }}$. The agricultural waste biomass anaerobic biodegradability with $\mathrm{B}_{\mathrm{u}} / \mathrm{B}_{\text {th }}$ and VDI4630 determined by VS contents was $36.0 \sim 95.9 \%$ and $30.8 \sim 91.1 \%$, respectively. Ultimate methane potential and anaerobic biodegradability given by the VS term showed more reasonable results.
\end{abstract}

Key words: Biochemical methane potential, Anaerobic biodegradability, Anaerobic digestion, Volatile solid, Agricultural waste biomass

Ultimate methane potential and anaerobic biodegradability given by the VS tem showed more reasonable results.

\begin{tabular}{|c|c|c|}
\hline \multirow{2}{*}{ Sample } & \multicolumn{2}{|c|}{ Anaerobic biodegradability } \\
\hline & $\mathrm{B}_{\mathrm{u}} / \mathrm{B}_{\mathrm{th}}^{\dagger}$ & $\mathrm{AB}_{\mathrm{VS}-\mathrm{VDI} 4630^{\ddagger}}$ \\
\hline & \multicolumn{2}{|c|}{ 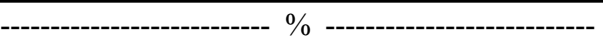 } \\
\hline Cucumber fruit & 95.3 & 87.1 \\
\hline Cucumber leaf & 86.5 & 76.8 \\
\hline Cucumber stem & 90.0 & 71.5 \\
\hline Tomato fruit & 64.6 & 68.8 \\
\hline Tomato leaf & 85.4 & 77.1 \\
\hline Tomato stem & 64.6 & 58.0 \\
\hline Paprika fruit & 70.8 & 91.1 \\
\hline Paprika leaf & 87.3 & 79.3 \\
\hline Paprika stem & 54.0 & 48.2 \\
\hline Adlay straw & 81.7 & 81.5 \\
\hline Chinese cabbage & 84.4 & 81.2 \\
\hline Radish & 57.7 & 44.0 \\
\hline Apple sludge & 95.9 & 89.3 \\
\hline Pear sludge & 36.0 & 30.8 \\
\hline Tangerine peel & 55.9 & 55.3 \\
\hline White paper sludge & 92.0 & 47.2 \\
\hline Yellow paper sludge & 67.0 & 40.3 \\
\hline
\end{tabular}

${ }^{\dagger}$ Ultimate methane potential / theoretical methane potential, ${ }^{\ddagger}$ VDI4630 method.

*Corresponding author : Phone: +82312900338, Fax:+82312900208, E-mail: sonnyk@korea.kr

${ }^{\S}$ Acknowledgement: This work was carried out with the support of "Cooperative Research Program for Agriculture Science \& Technology Development (Project No. PJ008620)" Rural Development Administration, Republic of Korea. 


\section{Introduction}

근래에 기후변화에 대응하여 이산화탄소의 감축 노력으 로 바이오매스 자원에 대한 관심이 증가하고 있는 추세이 다. 바이오매스는 최근 신재생에너지원의 한 분야인 바이 오에너지로 전환하는데 필요한 기초적인 재료로 사용되고 있으며, 바이오 에너지는 에탄올, 디젤, 가스 등으로 활용 하고 있으나, 식량 자급률이 낮은 국내 여건상 폐기물을 주로 활용하는 바이오가스를 생산하는 것이 적합하며, 최 근 축산업의 급속한 성장으로 축산계 폐기물의 발생량 또 한 증가하여 이를 처리하고 활용하는데 대한 관심이 증가 하고 있다.

바이오매스는 용도별로 자원식물계, 미이용계, 폐기물계 로 분류할 수 있는데, 그중 폐기물계 바이오매스는 방치할 경우 환경에 악영향을 초래할 소지가 있어 별도의 처리가 요구되고 있다. 이러한 바이오매스를 에너지로 전환하는 기 술로는 가스화 (Gasification), 열분해 (Pyrolysis), 단순연 소 (Combustion)에 의한 열화학적 변환 기술과 혐기성소화 (Anaerobic digestion)에 의한 생물학적 전환기술이 있으며, 이 중 가축분뇨, 하수슬러지, 작물잔사 등 유기성 바이오매 스를 이용하여 바이오가스를 생산하는 혐기소화 기술은 이 미 세계적으로 널리 보급된 기술이다. 혐기소화 기술은 각 종 유기성 바이오매스를 메탄 $\left(\mathrm{CH}_{4}\right)$ 으로 전환시키는 기술로 써 메탄생산효율은 원료로 이용되는 유기성 바이오매스의 메탄생산퍼텐셜 (Biochemical methane potential; BMP)에 의해 결정되게 된다 (Shin et al., 2011).

메탄생산퍼텐셜은 혐기소화 공정의 유입설계에서 원료의 종류 및 특성별로 바이오가스 및 메탄 생산 효율을 평가하 고 혐기소화 과정에서 나타날 수 있는 다양한 독성 및 저해 효과를 검토하는 중요한 정보를 제공하여 혐기소화 시설의 설계와 관리에 있어 가장 중요한 인자이다. 따라서 다양한 유기성 바이오매스에 대한 메탄생산퍼텐셜 측정 방법과 결과 는 국내외 많은 연구자들에 의해 보고되고 있다 (Angelidaki et al., 2009, Kim et al., 2010, Shin et al., 2011). 메탄생 산퍼텐셜 측정은 Owen et al. (1979)에 의해 회분식 (Batch) 혐기 반응기를 이용하여 투입 기질에 대한 메탄가스의 생산 수율을 산출하는 시험이 고안되었다. 그러나 메탄생산퍼텐 셜의 측정은 사용된 장비의 다양성 이외에도 혐기미생물 접종 액, 배지의 양분균형, $\mathrm{pH}$, 혐기반응기 안의 여유 공간 (Head space) 등의 메탄 생산퍼텐셜 분석 환경의 차이에서 따라 달라져 연구자 간에 유기물 분해율, 메탄생산퍼텐셜의 연구 결과를 직접 비교하는데 많은 어려움이 따른다 (Angelidaki et al., 2011; Raposo et al., 2006; Shelton and Tiedje, 1984). 따라서 국외 몇몇 나라들은 유기물의 메탄생산퍼텐셜과 혐 기적 유기물 분해율 측정을 위한 표준분석법을 확립하여 운
영하고 있다. 그중 독일은 VDI4630 (2006)을, 미국은 ASTM E2170-01 (2008)을 확립하여 다양한 유기물의 혐기분해율 분석을 실시하고 있으며, 특히 독일의 VDI4630은 회분식 혐기 반응기에서 생산되는 메탄의 수율을 산출하는데 반응 기의 운전 온도, 반응기 내 빈공간 (Head space), 가스의 압 력, 수분함량, $\mathrm{CH}_{4}$ 과 $\mathrm{CO}_{2}$ 농도, 접종액 (Inoculum)에 의한 가스발생량, 분석시료의 회분 (Ash) 함량 등을 보정하여 메 탄생산퍼텐셜 및 혐기적 유기물 분해율을 계산한다. 그러나 국내에는 아직 유기물의 메탄생산퍼텐셜의 측정을 위한 표 준 분석 방법과 유기물의 혐기적 분해율 계산법이 마련되어 있지 않은 실정이다. 따라서 본 연구에서는 농산부문에서 발생하는 17 종의 식물성 폐기물계 바이오매스를 선정하여 회분식 혐기반응기를 이용한 메탄생산퍼텐셜 분석을 통해 각 농산 바이오매스의 혐기적 유기물을 독일의 표준화 방법 의 하나인 VDI4630을 이용하여 유기물 분해율을 산출하였 고, 기존에 국내에서도 쓰여 왔던 이론적 메탄생산퍼텐셜 대비 실험적 메탄생산퍼텐셜 $\left(\mathrm{B}_{\mathrm{u}} / \mathrm{B}_{\mathrm{th}}\right)$ 법과 비교하여 표시함 으로써 혐기적 유기물 분해율을 비교·평가 하는데 목적을 두었다.

\section{Materials and methods}

시험재료 시설작물, 노지작물 및 부산물을 시험재료 로 채취하였는데, 시설작물은 경기도 안성지역에 위치한 오이 (재배면적 $9,900 \mathrm{~m}^{2}$ ), 토마토 (재배면적 $16,500 \mathrm{~m}^{2}$ ), 파프리카 (재배면적 $8,250 \mathrm{~m}^{2}$ ) 재배 하우스에서 2010년 8 월부터 10 월까지 재배 및 수확기간 중 농산 바이오매스 시 료를 채취하여 본 시험에 사용하였다. 한편, 노지작물로는 율무를 시험재료로 선정하였으며, 율무의 경우 재배 면적 이 적으나 바이오매스량이 크고 탈곡 후 부산물을 전량 폐 기한다는 점을 고려하여 선정하였다. 그 외에 김치, 쥬스 및 제지 생산시설에서 발생하는 부산물을 선정하여 시료 를 채취하여, 총 17 종의 성상이 다른 재료를 본 시험에 사 용하였다.

\section{이론적 메탄생산퍼텐셜 (Theoretical methane potential;}

$\mathbf{B}_{\text {th) }}$ 본 연구에서는 VS (Volatile solid) 기준 이론적 메탄 생산퍼텐셜 계산법을 사용하였다. 이론적 메탄생산퍼텐셜 은 바이오매스의 전원소 분석 결과를 기초로 Boyle (1976) 의 유기물 분해 반응식 (Eq. (1))을 이용하여 화학 양론적으 로 산출하였다. 산출한 이론적 메탄생산퍼텐셜은 $\left(\mathrm{B}_{\mathrm{th}}, \mathrm{Nm}^{3}\right.$ $\mathrm{kg}^{-1}-\mathrm{VS}_{\text {added }}$ ) 휘발성고형물 (Volatile solid) 함량을 기준으 로 표준상태 $\left(0^{\circ} \mathrm{C}, 1\right.$ 기압)에서의 이론적인 메탄 생산량으로 표현된다. 


$$
\begin{aligned}
& C_{a} H_{b} O_{c} N_{d} S_{e}+\left(a-\frac{b}{4}-\frac{c}{2}+\frac{3 d}{4}+\frac{e}{2}\right) H_{2} O \\
& \rightarrow\left(\frac{a}{2}+\frac{b}{8}-\frac{c}{4}-\frac{3 d}{8}-\frac{e}{4}\right) C H_{4} \\
& \quad+\left(\frac{a}{2}-\frac{b}{8}+\frac{c}{4}+\frac{3 d}{8}+\frac{e}{4}\right) C_{2}+d N H_{3}+e H_{2} S \\
& B_{t h-V S}\left(N^{3} k g^{-1}-V S_{a d d e d}\right)= \\
& 22.4 \times\left[\frac{(4 a+b-2 c-3 d-2 e) / 8}{12 a+b+16 c+14 d+32 e}\right] \\
& C_{a} H_{b} O_{c} N_{d} S_{e}+\left(a+\frac{b}{4}-\frac{c}{2}-\frac{3 d}{4}-\frac{e}{2}\right) O_{2} \\
& \rightarrow a C O_{2}+\left(\frac{b}{2}-\frac{3 d}{2}-e\right) H_{2} O+d N H_{3}+e H_{2} S
\end{aligned}
$$

\section{실험적 메탄생산퍼텐셜 시험 (Biochemical methane} potential assay; BMP assay) 메탄생산퍼텐셜 시험에 사 용한 접종액은 (Inoculum; I)은 경기도 안성에 위치하는 한 경대학교 바이오가스 상용화 연구시설에서 발생하는 혐기 소화액을 채취하였으며, 채취한 혐기소화액은 $2 \mathrm{~mm}$ 체를 통과시켜 후, $38^{\circ} \mathrm{C}$ 항온 배양기에서 배양하여 소화액 중의 이분해성의 유기물과 잔여가스를 충분히 제거하여 접종액 으로 사용하였다. 투입기질 (Substrate; S)은 기질의 휘발성 고형물 함량과 접종액의 휘발성 고형물 함량의 비율 (S/I ratio)이 0.5 가 되도록 조절하여 3 반복으로 혐기반응기를 준비하였다. 메탄생산퍼텐셜의 측정을 위한 회분식 혐기반 응기는 $160 \mathrm{~mL}$ serum bottle을 이용하였고, 상층부는 $\mathrm{N}_{2}$ 가 스를 충진하여 공기가 없는 상태에서 완전 밀폐시켜 중온 $\left(38^{\circ} \mathrm{C}\right)$ 에서 배양하였다. $38^{\circ} \mathrm{C}$ 항온 배양기에서 일일 1 회 손 으로 반응기를 흔들어 교반하면서 97일간 배양하였다. 또한 접종액에서 발생하는 메탄 가스를 보정하기 위하여 접종액 만을 투입한 3 반복의 혐기 반응기를 시료와 동일한 조건에 서 운영하였다.

메탄생산 퍼텐셜 시험 중에 발생하는 바이오가스는 Eq. (4)와 같이 온도와 수분을 보정하여 표준상태 $\left(0^{\circ} \mathrm{C}, 1\right.$ 기압) 에서의 건조가스 (dry gas)로 환산하여 누적 메탄생산곡선 을 구하였으며, Eq. (5)에서 $\mathrm{V}_{\mathrm{dry}}$ gas는 건조 가스의 부피,

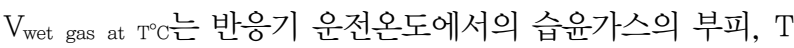
는 반응기의 운전온도, $\mathrm{P}$ 는 가스의 부피측정 당시의 기압, $\mathrm{P}_{\mathrm{T}}$ 는 $\mathrm{T}^{\circ} \mathrm{C}$ 에서의 포화수증기압 $(\mathrm{mmHg})$ 이다. 본 연구에서는 $\mathrm{P}$ 를 $760 \mathrm{mmHg}$ 로 간주하고 $\mathrm{P}_{\mathrm{T}}$ 는 $38^{\circ} \mathrm{C}$ 에서의 포화수증기압 으로 계산하였다.

$$
V_{\text {dry gas }}=V_{\text {wet gas at } T^{\circ} C} \times \frac{273}{(273+T)} \times \frac{\left(P-P_{T}\right)}{760}
$$

메탄생산퍼텐셜 시험을 통한 시험기질의 최대 메탄생산
퍼텐셜 (Ultimate methane potential; $\mathrm{B}_{\mathrm{u}}$ )은 Modified Gompertz model (Eq. (5))을 이용하여 산출하였다. Modified Gompertz model에서 $M$ 은 누적 메탄 생성량 $(\mathrm{mL}), P$ 는 최대 메탄 생 성량 $(\mathrm{mL}), R_{m}$ 은 메탄 생성 속도 $\left(\mathrm{mL} \mathrm{day}^{-1}\right), \lambda$ 는 지체성 장시간 (lag phase time, days), $t$ 는 혐기배양시간 (day), $e$ 는 $\exp (1)$ 을 의미한다.

$$
M=P \times \exp \left[-\exp \frac{R_{m}}{P}(\lambda-t) e+1\right]
$$

메탄생산퍼텐셜 시험에서는 누적 메탄생산 곡선을 이용 하여 배양기간별 메탄생산특성을 파악할 수 있으며, 혐기소 화 원료별로 지체성장시간, 혐기미생물 반응속도 등이 달라 지는 경우 혐기발효의 특성도 변화하게 된다. 따라서 이러 한 다양한 혐기발효 특성을 일반화 하여 최대 메탄생산량을 추정하는 다양한 함수식이 적용되어왔으며, 그중 Modified Gompertz model과 Exponential model이 일반적인 최대메 탄생산량 추정 모델이다. 그러나 exponential model은 혐기 미생물의 대수증식기의 성장 특성 해석에는 유리하지만, 긴 지체성장기를 가지는 미생물의 성장특성 및 반응속도의 해 석에는 어려움이 있다. 그에 비해 Gompertz model은 지체 성장기 (Lag growth phase), 대수증식기 (Exponential growth phase), 정체성장기 (Stationary growth phase)를 거치는 혐기미생물의 성장곡선을 잘 해석하는 특징이 있어 (Kim et al., 2010) 본 연구에서는 Modified Gomperz 모델로 해석하 였다.

\section{혐기적 유기물 분해율 (Anaerobic biodegradability)} 본 연구에서는 유기물의 혐기적 분해율을 산출하기 위해 독일의 VDI4630에 의하여 분해율을 산출하였으며, 기존에 주로 사용하던 혐기적 유기물 분해율인 $\mathrm{B}_{\mathrm{u}} / \mathrm{B}_{\mathrm{th}}$ 방법과 비교 하여 결과를 도출하였다. 기존 유기물의 혐기적 분해율을 나타내는 방법은 Eq. (6)을 사용하였다.

$$
A B_{i, C H_{4}}=\frac{B_{i, u}}{B_{t h}} \times 100
$$

여기서, $B_{i, u}$ 는 i번째 날의 메탄생산퍼텐셜 $\left(\mathrm{Nm}^{3} \mathrm{~kg}^{-1}-\mathrm{VS}_{\mathrm{added}}\right)$, $B_{t h}$ 는 이론적 메탄생산퍼텐셜 $\left(\mathrm{Nm}^{3} \mathrm{~kg}^{-1}-\mathrm{VS}_{\mathrm{added}}\right)$ 이다.

다음의 Eq. (7)은 VDI4630에 의한 유기물 분해율 산출식이 다. VDI4630은 독일에서 사용하는 혐기적 유기물 분해율을 계산하는 방법으로 미국의 ASTM과 함께 널리 쓰이고 있다.

$$
\begin{aligned}
& A B_{i, V S-V D I 4630}= \\
& \frac{V_{i, \text { biogas }} \times C_{i, C H_{4}+C O_{2}}}{m_{\text {substrate }} \times\left(V S_{\text {substrate }}+V F A_{\text {substrate }}\right) \times 0.93} \times 100(\%)
\end{aligned}
$$




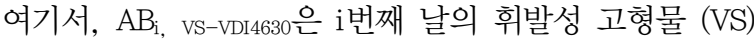

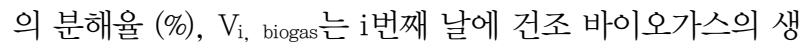

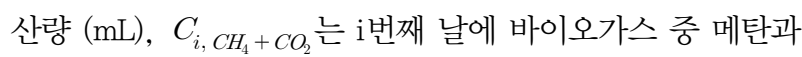
이산화탄소의 질량분율 $\left(\mathrm{g} \mathrm{mL}^{-1}\right), \mathrm{m}_{\text {substrate }}$ 는 기질의 질량 $(\mathrm{g})$, $\mathrm{VS}_{\text {substrate}}$ 는 기질의 VS 농도 $\left(\mathrm{g} \mathrm{g}^{-1}\right), \mathrm{VFA}_{\text {substrate }}$ 는 기질의 휘 발성 지방산 $(\mathrm{VFA})$ 의 농도 $\left(\mathrm{g} \mathrm{g}^{-1}\right), 0.93$ 은 $\mathrm{VS}$ 중 바이오가 스 전환율로 나타낸다. 실제 실험에서 혐기소화 미생물 반응 중 유입 유기물의 약 5 10\%는 혐기 미생물 균체 (Biomass) 를 증식하는데 이용되기 때문에 바이오가스 전환율 $7 \%$ 를 낮 게 책정한 것이다. VDI4630의 분해율 산출식에서 $C_{i, \mathrm{CH}_{4}+\mathrm{CO}_{2}}$ 산출을 위한 메탄과 이산화탄소의 농도는 Eq. (8)을 이용하 여 보정하여 사용한다. 이는 유기물에서 기인하는 바이오가 스의 주성분이 메탄과 이산화탄소라고 가정하여 바이오가 스 전량을 메탄과 이산화탄소로 보정하여 주는 식이다.

$$
C_{i, \mathrm{CH}_{4}\left(\mathrm{CO}_{2}\right)-\mathrm{corr}}=C_{i, \mathrm{CH}_{4}\left(\mathrm{CO}_{2}\right)} \times \frac{100}{C_{i, \mathrm{CH}_{4}}+C_{i, \mathrm{CO}_{2}}}
$$

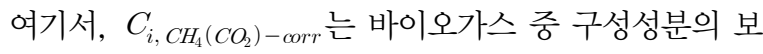
정농도 $\left(\%, \mathrm{v} \mathrm{v}^{-1}\right), C_{i, \mathrm{CH}_{4}\left(\mathrm{CO}_{2}\right)}$ 는 i번째 날에 바이오가스 중 메 탄 또는 이산화탄소의 측정농도 $\left(\%, \mathrm{v} \mathrm{v}^{-1}\right), C_{i, C H_{4}}$ 는 I번째 날에 바이오가스 중 메탄의 측정농도 $\left(\%, \mathrm{v} \mathrm{v}^{-1}\right), C_{i, C O}$ 는 I 번째 날에 바이오가스 중 이산화탄소의 측정농도 $C_{i, C O_{2}}$ 이다.
분석방법 회분식 혐기반응기의 바이오가스 발생량 측 정은 $2 \%$ 황산에 rsazurin $0.1 \%$ 를 함유하는 수주차식 측정기 를 사용하였으며 (Beuvink et al., 1992; Willams et al., 1996), 바이오가스의 가스성분분석은 TCD (Thermal conductivity detector)가 장착된 Gas chromatography (Clarus 680, PerkinElmer, USA)를 이용하였다. 컬럼은 Hayesep Q packed column $(3 \mathrm{~mm} \times 3 \mathrm{~m}, 80 \sim 100 \mathrm{mesh}$ size)을 이용하였으며, 고 순 도의 아르곤 $(\mathrm{Ar})$ 가스를 이동상으로 사용하여 flow $30 \mathrm{~mL}$ $\mathrm{min}^{-1}$ 의 운전 상태에서 주입부 (Injector) 온도 $150^{\circ} \mathrm{C}$, 컬럼 부 (Column oven) $90^{\circ} \mathrm{C}$, 검출부 (Detector) $150^{\circ} \mathrm{C}$ 에서 분석 하였다 (Sorensen et al., 1991). 기질의 전 원소분석은 원소 분석기 (EA1108, Thermo Finnigan, CA)를 사용하였으며, 총고형물 (Total solid; TS), 휘발성 고형물 (Volatile solid; $\mathrm{VS}$ ), 화학적 산소 요구량 (Chemical oxygen remand; COD), 암모니아성 질소 $\left(\mathrm{NH}_{4}{ }^{+}-\mathrm{N}\right)$, 총질소 (Total nitrogen; $\mathrm{TN}$ ) 등은 Standard methods (APHA, 1998)에 따라 3반복으로 분석하였다.

\section{Results and Discussion}

시료의 이화학성 본 시험에서 사용된 시험재료의 이 화학성은 Table 1 과 같다. 총 고형물 (TS) 함량은 주로 제지 슬러지를 제외한 가공부산물이 높은 함량 분포를 보여주고 있다. 혐기소화 과정에서 바이오가스로 전환되는 유기물의

Table 1. Chemical characteristics of agricultural waste biomass.

\begin{tabular}{|c|c|c|c|c|c|c|c|c|c|c|c|c|c|c|}
\hline Sample & $\mathrm{TS}^{\dagger}$ & $\mathrm{VS}^{\ddagger}$ & $\mathrm{TN}^{\S}$ & $\mathrm{TP}^{\mathbf{q}}$ & $\overline{\mathrm{K}}$ & $\mathrm{Ca}$ & $\mathrm{Mg}$ & $\mathrm{Na}$ & $\mathrm{Fe}$ & $\mathrm{Co}$ & $\mathrm{Ni}$ & Mo & $\mathrm{Cu}$ & $\mathrm{Zn}$ \\
\hline & 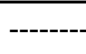 & . & 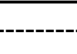 & $\mathrm{g} \mathrm{kg}^{-1}$ & & & 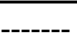 & & & 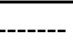 & $\mathrm{mg} \mathrm{kg}$ & & & ------ \\
\hline Cucumber fruit & 32.8 & 28.5 & 36.0 & 0.62 & 1.75 & 0.23 & 0.13 & 0.01 & 0.02 & 0.02 & 0.13 & 0.09 & 1.00 & 6.78 \\
\hline Cucumber leaf & 144.9 & 111.5 & 39.9 & 2.95 & 4.14 & 3.91 & 1.60 & 0.05 & 0.56 & 0.06 & 1.11 & 0.17 & 4.39 & 39.39 \\
\hline Cucumber stem & 103.3 & 85.1 & 18.5 & 2.30 & 6.07 & 2.12 & 0.66 & 0.03 & 0.10 & 0.05 & 0.76 & 0.17 & 3.22 & 35.89 \\
\hline Tomato fruit & 79.7 & 72.8 & 18.4 & 0.57 & 1.16 & 0.11 & 0.14 & 0.03 & 0.16 & 0.02 & 0.51 & 0.19 & 57.1 & 15.76 \\
\hline Tomato leaf & 116.1 & 85.3 & 30.4 & 0.99 & 5.84 & 3.10 & 0.84 & 0.17 & 0.18 & 0.08 & 0.49 & 0.38 & 2.50 & 11.56 \\
\hline Tomato stem & 108.3 & 94.7 & 15.8 & 0.79 & 4.79 & 1.52 & 0.50 & 0.11 & 0.09 & 0.04 & 0.43 & 0.30 & 2.39 & 24.76 \\
\hline Paprika fruit & 74.43 & 69.0 & 22.6 & 0.63 & 2.34 & 0.10 & 0.11 & 0.02 & 0.07 & 0.02 & 0.17 & 0.11 & 1.40 & 22.29 \\
\hline Paprika leaf & 154.3 & 122.1 & 43.2 & 1.69 & 14.01 & 4.14 & 0.86 & 0.12 & 0.19 & 0.19 & 0.95 & 0.17 & 41.18 & 106 \\
\hline Paprika stem & 164.4 & 144.4 & 24.6 & 1.16 & 9.77 & 1.56 & 0.49 & 0.10 & 0.10 & 0.07 & 0.66 & 0.41 & 5.43 & 39.39 \\
\hline Adlay straw & 390 & 351.6 & 13.7 & 4.27 & 5.03 & 1.36 & 0.65 & 0.09 & 0.32 & 0.39 & 4.42 & 5.02 & 0.39 & 45.3 \\
\hline Chinese cabbage & 67.4 & 53.6 & 44.4 & 0.96 & 2.88 & 1.25 & 0.16 & 0.03 & 0.092 & 0.08 & 0.25 & 0.28 & 1.22 & 11.71 \\
\hline Radish & 165.1 & 121.5 & 48.4 & 1.37 & 1.98 & 1.99 & 0.28 & 0.81 & 0.14 & 0.04 & 1.04 & 0.06 & 22.37 & 12.41 \\
\hline Apple sludge & 162.4 & 157.5 & 0.8 & 0.26 & 0.86 & 0.08 & 0.06 & 0.04 & 0.13 & 0.06 & 1.41 & 3.10 & 2.07 & 10.53 \\
\hline Pear sludge & 219.7 & 211.2 & 8.7 & 1.63 & 0.64 & 0.09 & 0.31 & 0.01 & 0.16 & 0.03 & 1.69 & 0.25 & 90.81 & 22.6 \\
\hline Tangerine peel & 296.3 & 249.1 & 11.1 & 1.18 & 1.40 & 0.52 & 0.64 & 0.07 & 0.32 & 0.03 & 1.94 & 0.25 & 306.5 & 61.97 \\
\hline White paper sludge & 27.3 & 11.5 & 7.3 & - & 0.002 & 0.16 & 0.01 & 0.01 & 0.02 & - & 0.98 & - & - & - \\
\hline Yellow paper sludge & 38.9 & 17.5 & 6.7 & - & 0.002 & 0.23 & 0.02 & 0.01 & 0.004 & - & 0.94 & - & - & - \\
\hline
\end{tabular}

${ }^{\dagger}$ Total solid content, ${ }^{\dagger}$ Volatile solid content, ${ }^{\S}$ Total nitrogen content, ${ }^{\dagger}$ Total phosphorous content. 
지표인 휘발성 고형물 (VS)은 오이, 토마토, 파프리카의 줄 기에서 총고형물 함량에 비추어 볼 때 주로 열매에서의 가 용성 유기물의 함량이 높고, 잎에서 가용성 유기물의 함량 이 낮게 나타났다. 그중 노지작물인 율무는 TS 함량과 VS함 량이 $390 \mathrm{~g} \mathrm{~kg}^{-1}, 351 \mathrm{~g} \mathrm{~kg}^{-1}$ 으로 가장 높게 나타났으며, 배 추는 총고형물 함량이 $67 \mathrm{~g} \mathrm{~kg}^{-1}$, 휘발성 고형물 함량이 54 $\mathrm{g} \mathrm{kg}^{-1}$ 로 상대적으로 낮았으며, 무청은 $122 \mathrm{~g} \mathrm{~kg}^{-1}$ 으로 나타 났다. 쥬스 가공부산물인 사과, 배 및 귤껍질은 $158 \sim 249 \mathrm{~g}$ $\mathrm{kg}^{-1}$ 으로 대체로 높은 유기물 함량을 보였다. 그러나 제지 슬러지는 $12 \sim 18 \mathrm{~g} \mathrm{~kg}^{-1}$ 로 가장 낮은 휘발성 고형물 함량을 보였다.

\section{이론적 메탄생산퍼텐셜 (Theoretical methane potential;}

$\mathbf{B}_{\text {th) }}$ 농산 바이오매스의 전원소 분석결과로 계산한 이론적 메탄생산퍼텐셜은 Table 2 와 같다. 농산바이오매스의 이론 적 메탄생산퍼텐셜은 배 슬러지가 $0.488 \mathrm{Nm}^{3} \mathrm{~kg}^{-1}-\mathrm{VS}_{\text {added }}$ 로 가장 높은 값을 나타내었고, 황지 제지공정 폐수슬러지 가 $0.266 \mathrm{Nm}^{3} \mathrm{~kg}^{-1}-\mathrm{VS}_{\mathrm{added}}$ 로 가장 낮은 이론적 메탄생산퍼 텐셜을 보였다. 제지슬러지를 제외하고는 $0.352 \sim 0.488 \mathrm{Nm}^{3}$

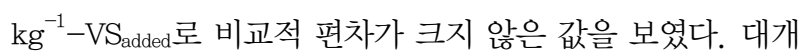
동물성 바이오매스와 같이 단백질 및 지방 함량이 높을 경 우 이론적 메탄생산퍼텐셜이 높은 값을 주로 보이게 된다 (Shin et al., 2011). 반면에 식물성 특성을 지니는 바이오매

Table 2. Elemental composition and theoretical methane potential of agricultural waste biomass.

\begin{tabular}{ccccccc}
\hline \hline Sample & $\mathrm{C}$ & $\mathrm{H}$ & $\mathrm{O}$ & $\mathrm{N}$ & $\mathrm{S}$ & $\mathrm{B}_{\mathrm{th}}^{\dagger}$ \\
\hline & --------- & $\%$ & $(\mathrm{w} / \mathrm{w})$ & -------- & $\mathrm{Nm}^{3} \mathrm{~kg}^{-1}$ \\
$-\mathrm{VS}_{\mathrm{added}}$ & & & & & & 0.418 \\
Cucumber fruit & 42.4 & 5.6 & 41.0 & 3.6 & 0 & 0.45 \\
Cucumber leaf & 38.9 & 5.3 & 34.9 & 4.0 & 0.2 & 0.435 \\
Cucumber stem & 36.1 & 4.6 & 43.3 & 1.9 & 0 & 0.352 \\
Tomato fruit & 48.6 & 5.6 & 41.3 & 1.8 & 0 & 0.464 \\
Tomato leaf & 37.7 & 4.9 & 38.6 & 3.0 & 2.2 & 0.480 \\
Tomato stem & 41.7 & 5.4 & 46.2 & 1.6 & 0.2 & 0.386 \\
Paprika fruit & 47.5 & 6.3 & 39.7 & 2.3 & 0 & 0.485 \\
Paprika leaf & 40.1 & 5.1 & 38.8 & 4.3 & 0.1 & 0.399 \\
Paprika stem & 40.2 & 5.1 & 43.3 & 2.5 & 0.4 & 0.382 \\
Adlay straw & 41.8 & 5.6 & 40.2 & 1.4 & 0.2 & 0.444 \\
Chinese cabbage & 40.7 & 5.3 & 37.6 & 4.4 & 0.3 & 0.416 \\
Radish & 42.7 & 5.4 & 39.2 & 4.8 & 0.5 & 0.413 \\
Apple sludge & 43.4 & 6.4 & 49.7 & 0.1 & 0 & 0.410 \\
Pear sludge & 49.3 & 6.4 & 42.3 & 0.9 & 0 & 0.488 \\
Tangerine peel & 46.9 & 6.3 & 45.1 & 1.1 & 0 & 0.449 \\
White paper sludge & 25.5 & 2.9 & 34.2 & 0.7 & 0.5 & 0.303 \\
Yellow paper sludge & 24.9 & 2.5 & 36.0 & 0.7 & 0.7 & 0.262 \\
\hline
\end{tabular}

${ }^{\dagger}$ Theoretical methane potential.
스는 그 특성상 지방과 단백질의 함량이 낮기 때문에 이론 적 메탄생산퍼텐셜 또한 낮게 나타난 것으로 볼 수가 있다.

\section{실험적 메탄생산퍼텐셜 (Ultimate methane potential;}

$\mathbf{B}_{\mathbf{u}}$ 공시재료의 메탄생산퍼텐셜은 Table 3과 같으며, 97 일간의 메탄생산퍼텐셜 시험을 통해 얻은 누적 메탄생산 곡 선과 투입 유기물 당 메탄생산량은 각각 Fig. $1,2,3,4,5$, 6,7 과 같았다. 시설하우스 채소 부산물의 경우 각각 열매, 잎, 줄기의 누적 메탄생산량을 산정한 결과 열매와 잎에 비 해 줄기에서의 메탄생산량이 현저히 낮은 것을 본 연구를 통해 알 수 있었다. 이것은 본 시험에서 사용한 원예채소작 물의 줄기는 잎이나 열매에 비해 주로 단단한 조직의 함량 이 높아, 상대적으로 리그닌의 함량이 높은 탓에 미생물의 분해가 더딘 것으로 판단되었다. 실제로 리그닌은 토양내에 유기물로 투입이 된다 하더라도 이분해성 유기물에 비해 분 해가 잘 일어나지 않아 부식으로 전환되는 비율이 매우 높 다는 것은 선행연구를 통해 이미 잘 알려진 사실이다. 시설 원예작물의 최대 메탄생산퍼텐셜은 $0.417 \mathrm{Nm}^{3} \mathrm{~kg}^{-1}-\mathrm{VS}_{\text {added }}$ 로 토마토잎이 가장 높았으며 파프리카 줄기가 $0.207 \mathrm{Nm}^{3}$ $\mathrm{kg}^{-1}-\mathrm{VS}_{\text {added }}$ 로 가장 낮아, 줄기를 제외하면 $0.343 \mathrm{Nm}^{3} \mathrm{~kg}^{-1}$ $-\mathrm{VS}_{\mathrm{added}}$ 이상의 메탄퍼텐셜을 보여 해외의 연구사례와 큰

Table 3. Parameters of methane production curve estimated by the modified Gompertz equation in the agricultural waste biomass.

\begin{tabular}{ccccc}
\hline \hline Sample & $\mathrm{B}_{\mathrm{u}}^{\dagger}$ & $\mathrm{P}^{\ddagger}$ & $\mathrm{R}_{\mathrm{m}}{ }^{\S}$ & $\lambda^{\uparrow}$ \\
\hline & $\begin{array}{c}\mathrm{Nm}^{3} \mathrm{~kg}^{-1} \\
-\mathrm{VS}_{\text {added }}\end{array}$ & $\mathrm{mL}$ & $\mathrm{mL}$ day & day \\
Cucumber fruit & 0.398 & 397.3 & 38.2 & 0.4 \\
Cucumber leaf & 0.377 & 378.2 & 32.7 & 0.8 \\
Cucumber stem & 0.317 & 427.7 & 31.2 & 0.5 \\
Tomato fruit & 0.300 & 237.9 & 17.2 & - \\
Tomato leaf & 0.417 & 299.8 & 33.3 & 1.2 \\
Tomato stem & 0.250 & 197.5 & 19.5 & 0.7 \\
Paprika fruit & 0.343 & 391.8 & 33.3 & 0.4 \\
Paprika leaf & 0.358 & 294.3 & 11.2 & 0.2 \\
Paprika stem & 0.207 & 167.2 & 16.7 & 0.8 \\
Adlay straw & 0.364 & 291.8 & 25.4 & - \\
Chinese cabbage & 0.352 & 278.1 & 22.8 & 1.1 \\
Radish & 0.279 & 131.5 & 8.8 & 0.3 \\
Apple sludge & 0.393 & 405.9 & 32.0 & 0.6 \\
Pear sludge & 0.176 & 83.1 & 3.5 & - \\
Tangerine peel & 0.279 & 160.2 & 8.7 & - \\
White paper sludge & 0.281 & 123.1 & 13.8 & 2.2 \\
Yellow paper sludge & 0.178 & 116.8 & 11.9 & 1.8 \\
\hline
\end{tabular}

${ }^{\dagger}$ Ultimated methane potential, ${ }^{\ddagger}$ Methane production, ${ }^{\S}$ Specific methane production rate, "Lag phase time. 

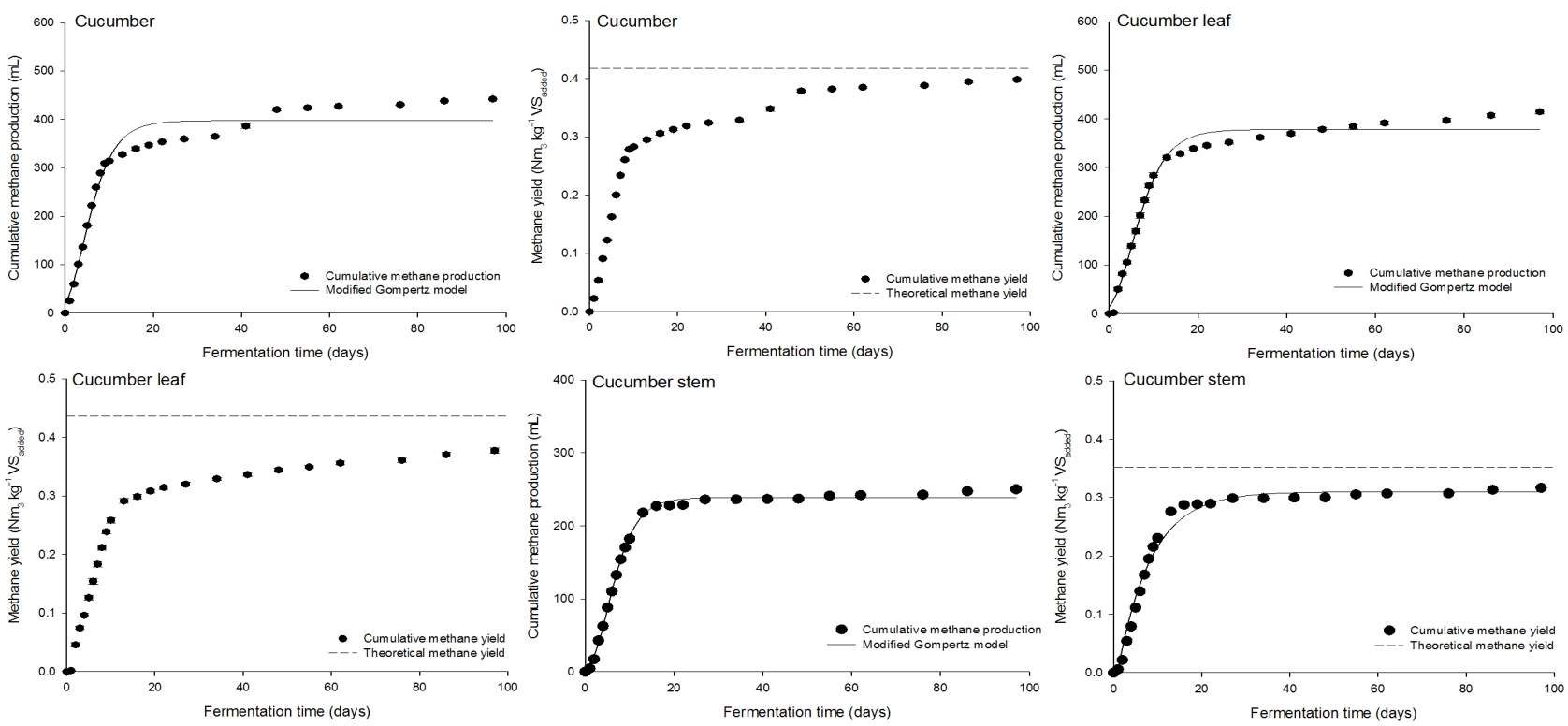

Fig. 1. Cumulative methane productions and yields of cucumber biomass during batch anaerobic digestion.
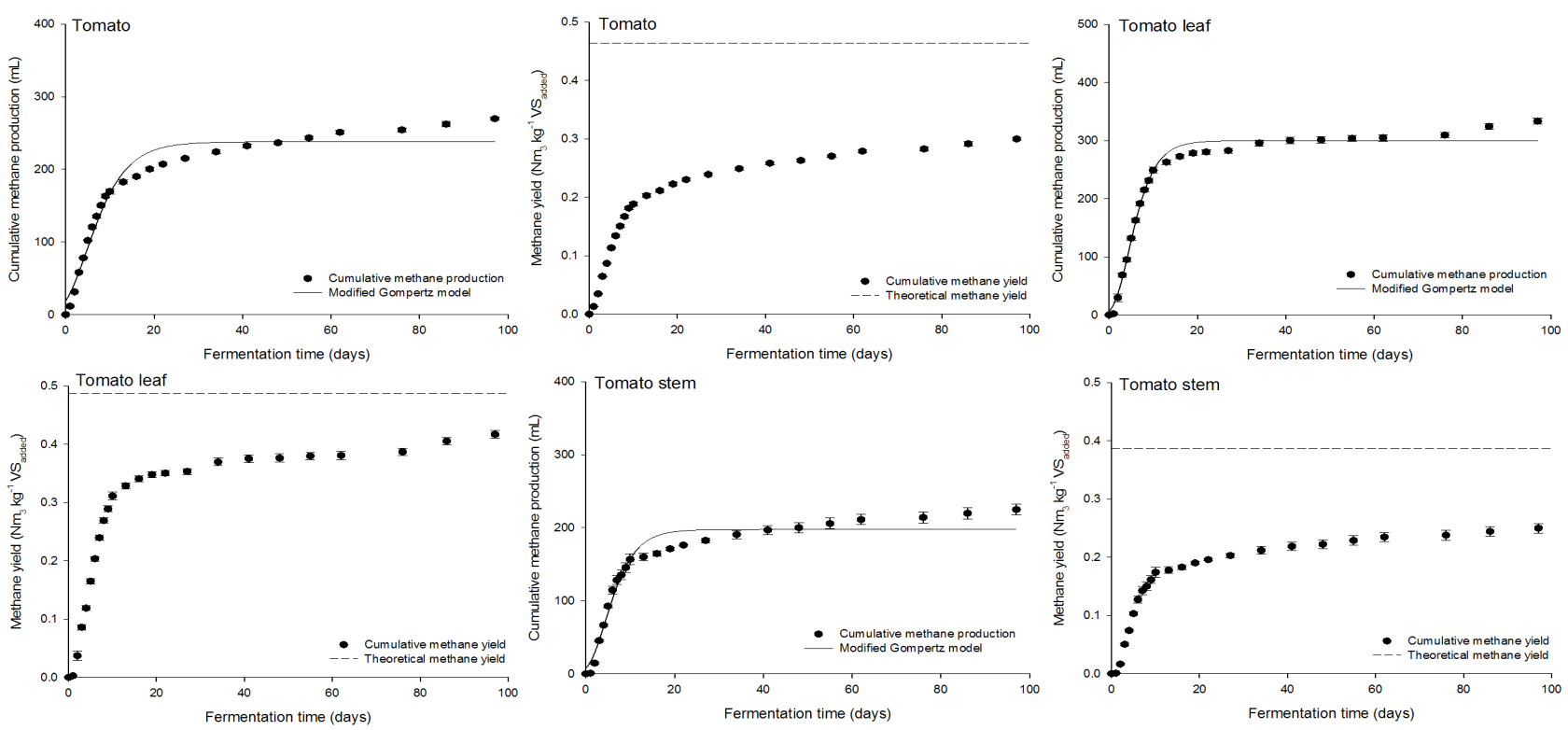

Fig. 2. Cumulative methane productions and yields of tomato biomass during batch anaerobic digestion.

차이를 보이지 않았다 (Buffiere et al., 2006; Gunaseelan, 1997). 노지 작물인 율무는 $0.364 \mathrm{Nm}^{3} \mathrm{~kg}^{-1}-\mathrm{VS}_{\text {added }}$ 의 결과 를 보여 시설원예작물과 큰 차이가 없었으나, 그 외 가공장 슬러지류는 대체로 메탄생산퍼텐셜이 낮았다. 특히 배 가공슬 러지와 황지제지공정 슬러지가 각각 $0.176 \mathrm{Nm}^{3} \mathrm{~kg}^{-1}-\mathrm{VS}_{\text {added}}$, $0.178 \mathrm{Nm}^{3} \mathrm{~kg}^{-1}-\mathrm{VS}_{\mathrm{added}}$ 로 매우 낮은 수치를 보였다. 이는 여러 단계의 제조 공정을 거치면서 미생물이 활용할 수 있 는 유기물이 많이 소진되었거나, 제지공정 단계는 여러 물 리·화학적 공정 (탈질, 탈인 공정 등)을 거치며 상대적 VS함 량이 낮았기 때문인 것으로 풀이된다. 일 최대메탄생산량 $\left(\mathrm{R}_{\mathrm{m}}\right)$ 을 보면 오이의열매, 잎, 줄기가 각각 $38.2,32.7,31.2$ $\mathrm{mL} \mathrm{day}{ }^{-1}$ 로 대체로 높았고, 토마토의 경우 열매, 잎, 줄기
가 각각 $17.2,33.3,19.5 \mathrm{~mL} \mathrm{day}^{-1}$ 였으며, 파프리카의 경 우, 각각 $33.3,11.2,16.7 \mathrm{~mL} \mathrm{day}{ }^{-1}$ 의 결과를 보였다. 지체 성장시간은 농산부산물 전체적으로 매우 짧았으며 토마토, 율무, 배 슬러지, 사과슬러지는 지체성장 시간이 없었으며, 나머지 부산물도 대부분 1 일 미만으로 매우 짧은 지체 성장 시간을 보였다. 이것은 식물계 바이오매스의 주요성분인 셀 룰로오스 함량이 미생물의 지체성장기에 미치는 영향이 없 다는 것을 간접적으로 보여 주는 결과라 볼 수 있다.

본 농산부산물의 메탄생산퍼텐셜의 결과로 보아 시설원 예지, 노지 등에서 재배되어 버려지는 폐기물 또는 부산물 들을 통합 혐기소화 시 많은 민원이 발생하는 기존의 음식 물 쓰레기나 하수슬러지를 대체하여 자원 순환이라는 개념 

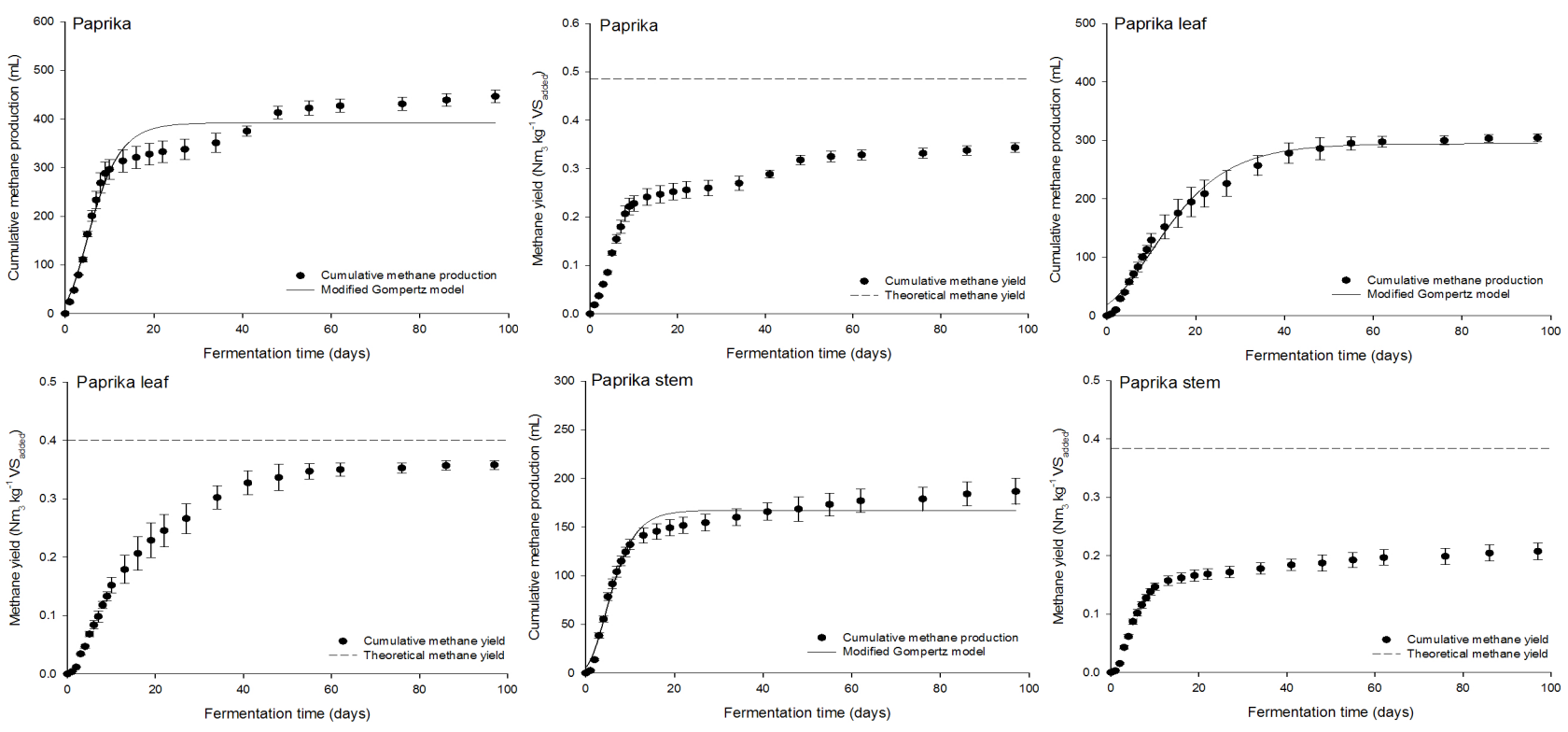

Fig. 3. Cumulative methane productions and yields of Paprika biomass during batch anaerobic digestion.
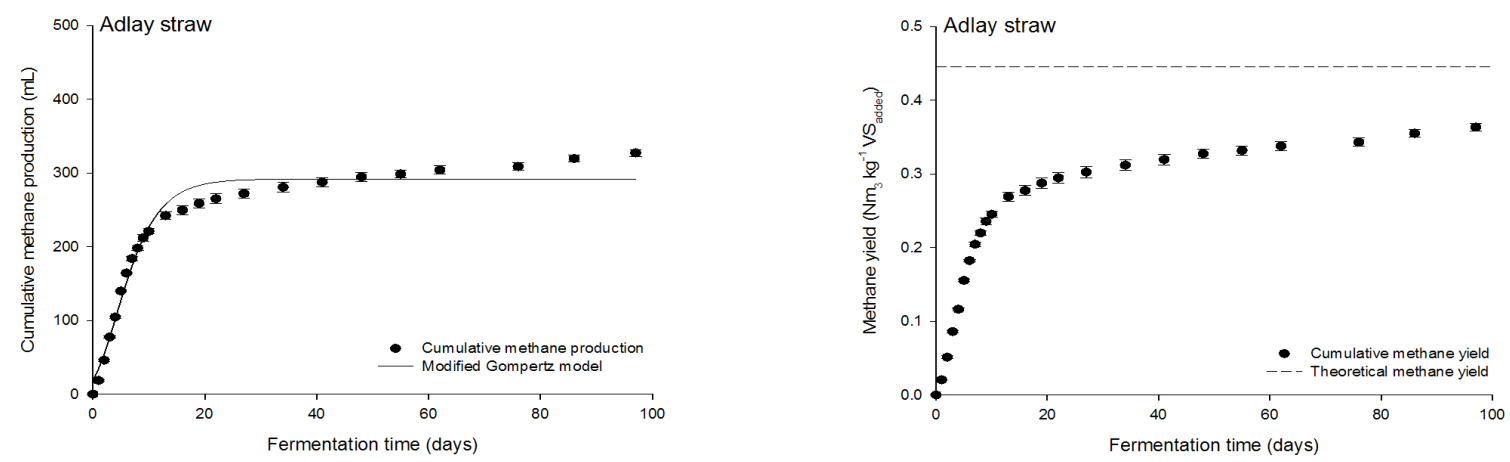

Fig. 4. Cumulative methane productions and yields of adlay straw biomass during batch anaerobic digestion.
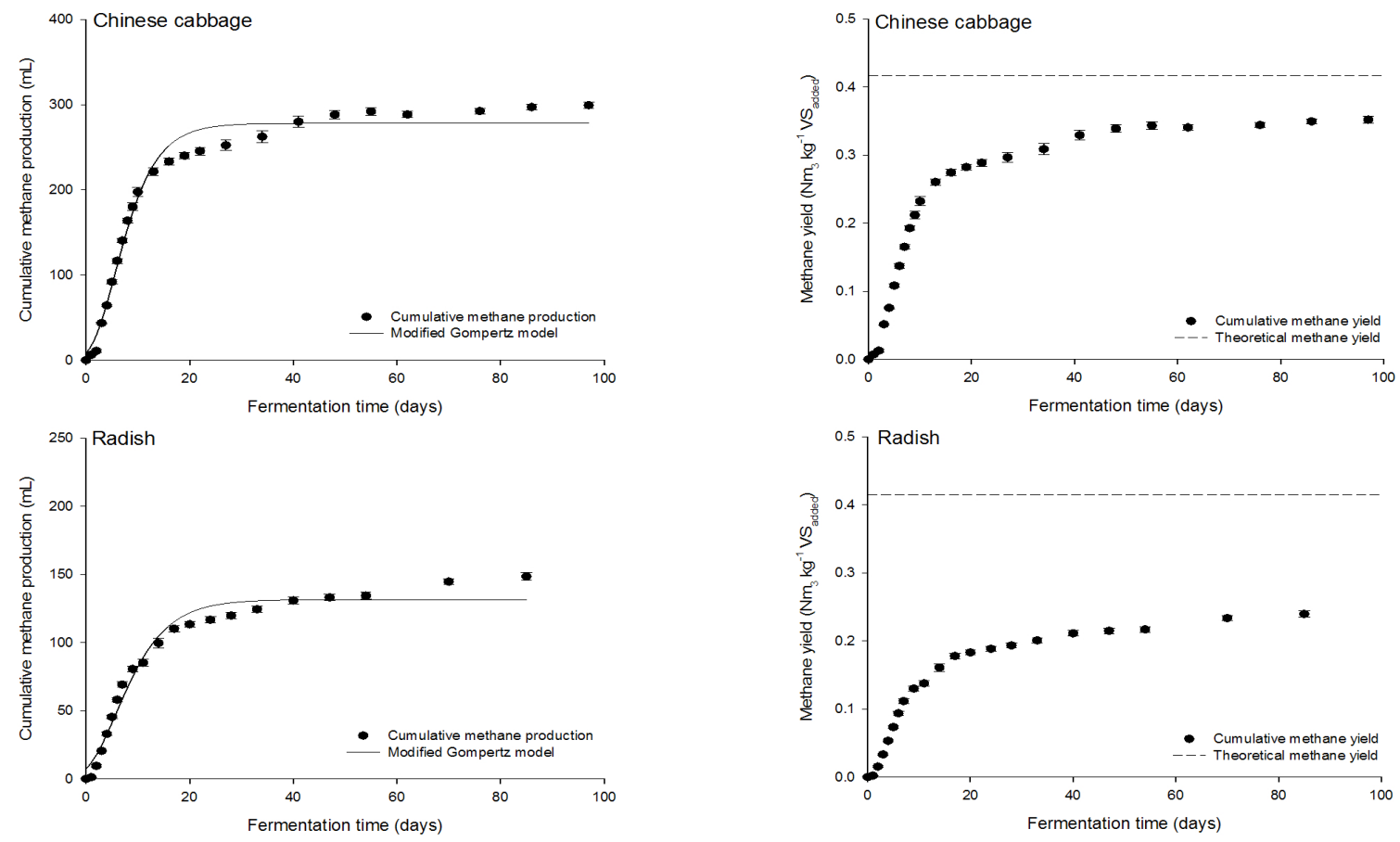

Fig. 5. Cumulative methane productions and yields of Kimchi process waste biomass during batch anaerobic digestion. 

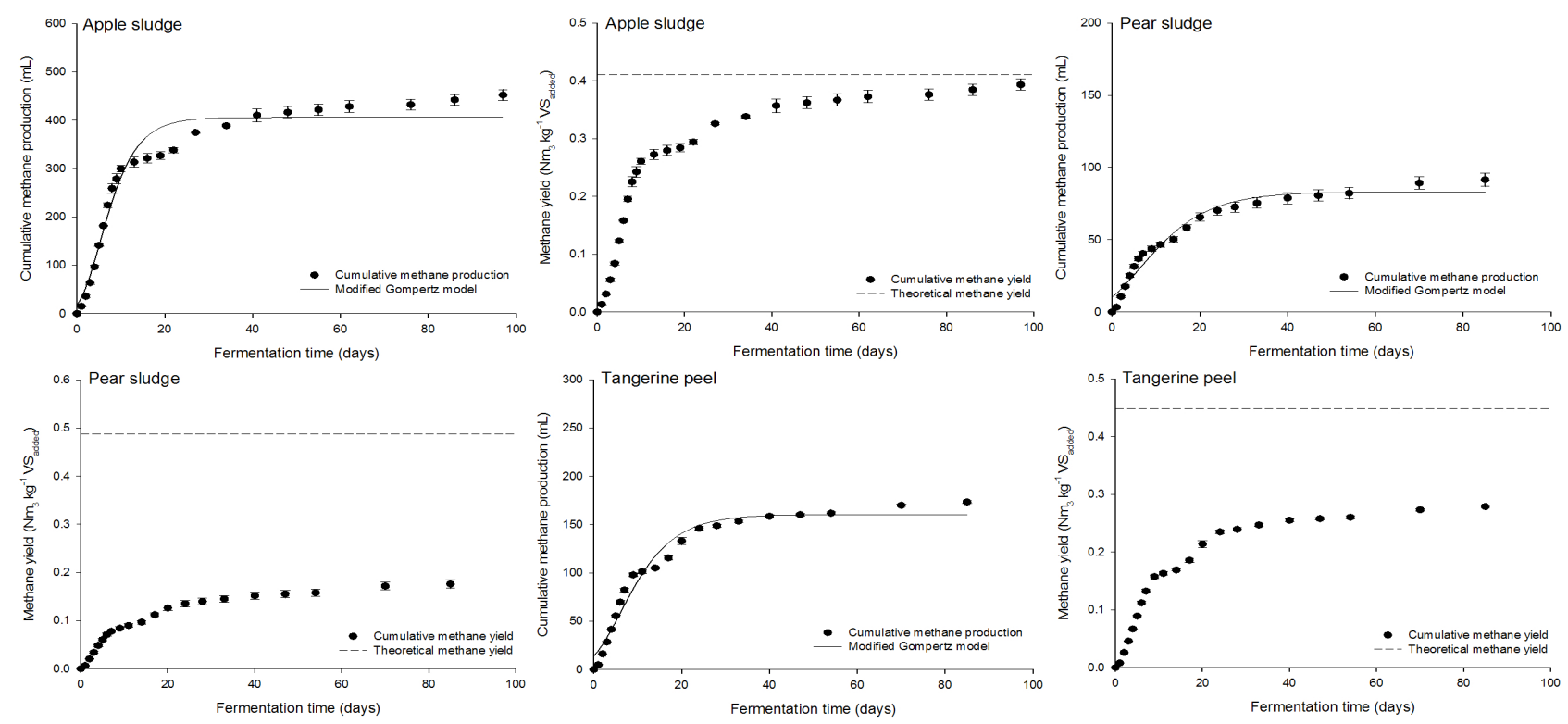

Fig. 6. Cumulative methane productions and yields of juice process waste biomass during batch anaerobic digestion.
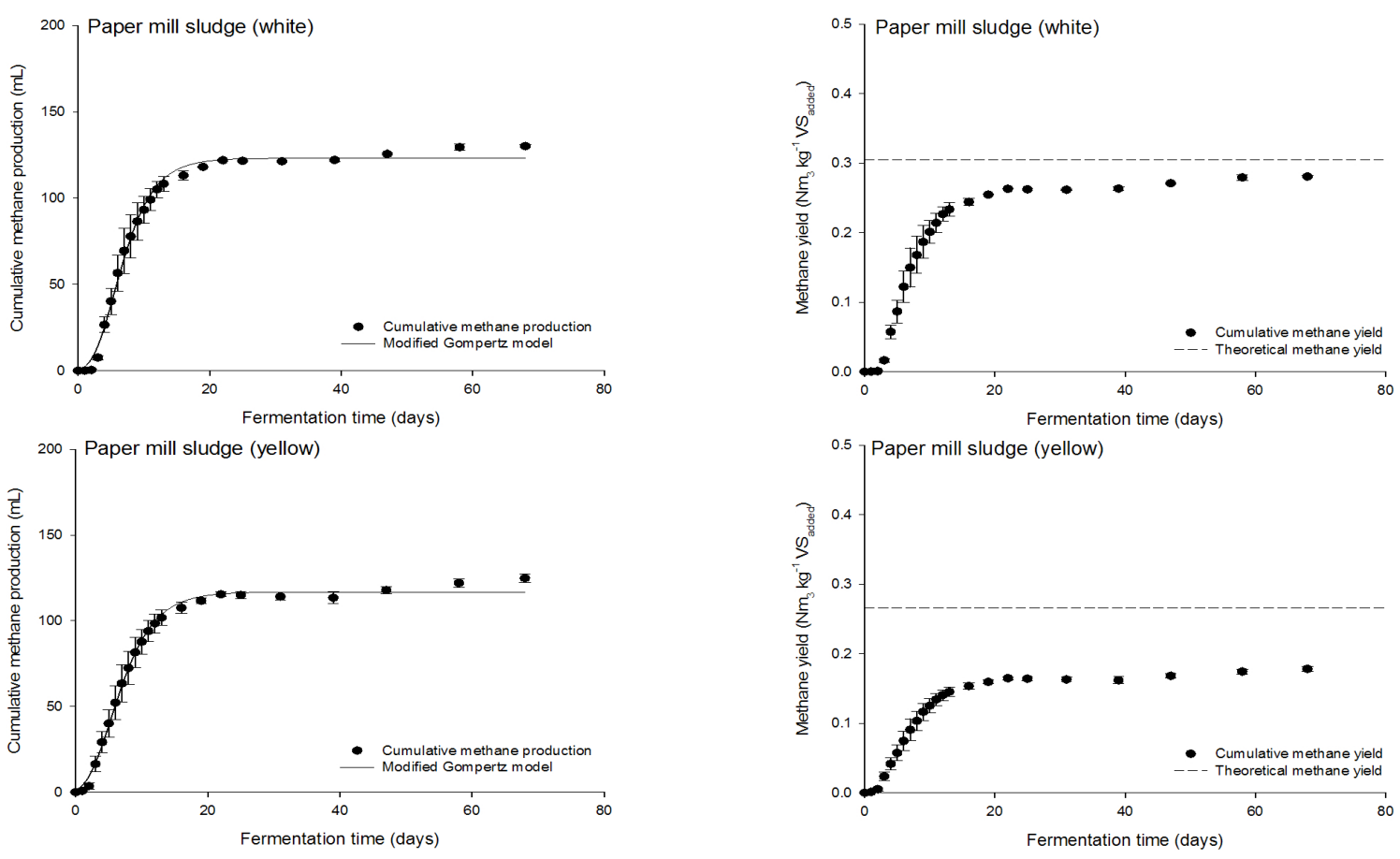

Fig. 7. Cumulative methane productions and yields of paper plant waste biomass during batch anaerobic digestion.

하의 농산폐기물 활용은 매우 긍정적 효과가 있을 것으로 판단되어 진다. 그러나 현재 국내에는 농·축산 부산물에 대 한 메탄생산퍼텐셜에 대한 연구가 부족하여, 바이오가스 생 산에 활용할 소재가 많지 않은 실정이어서, 향후 연구가 더 욱 진행 되어야 할 부분이다.

혐기적 유기물 분해율 평가 농산 바이오매스의 이론 적 메탄생산퍼텐셜 대비 실험적 메탄생산퍼텐셜 $\left(\mathrm{B}_{\mathrm{u}} / \mathrm{B}_{\mathrm{th}}\right)$ 의 비율로 산출하는 유기물 분해율과 VDI4630에 근거한 유기 물 분해율 (Anaerobic biodegradability; $\mathrm{AB}$ )은 Table 4와
같다. 분해율을 비교해 보면 파프리카와 토마토를 제외하고 는 모든 분해율은 $\mathrm{B}_{\mathrm{u}} / \mathrm{B}_{\mathrm{th}}$ 보다 VDI4630에서 낮은 경향을 보 였다. 오이의 경우 $\mathrm{B}_{\mathrm{u}} / \mathrm{B}_{\mathrm{th}}$ 가 86 95.3\%로 매우 높게 평가 되었으나, VDI4630은 71.5 87.1\%의 범위를 보여 낮게 평 가되었다. 토마토 부산물의 경우와 파프리카 부산물의 경우 도 분해율이 VDI4630법이 낮게 평가 되었으며, 범위는 각 각 58 77.1\%, 48 91\%였다. 특히 농산바이오매스는 줄기 에서 낮은 분해율을 보이고 있는데, 이것은 대부분의 유기 물이 세포벽에 의해 차단되어 있으므로, 혐기성 소화균이 유기물을 분해하여 최종적으로 메탄과 이산화탄소를 생성 
Table 4. Anaerobic biodegradability estimated by different analytical methods on agricultural waste biomass.

\begin{tabular}{ccc}
\hline \hline \multirow{2}{*}{ Sample } & \multicolumn{2}{c}{ Anaerobic biodegradability } \\
\cline { 2 - 3 } & $\mathrm{B}_{\mathrm{u}} / \mathrm{B}_{\mathrm{th}}{ }^{\dagger}$ & $\mathrm{AB}_{\mathrm{VS}-\mathrm{VD} \text { 4630 }}{ }^{\ddagger}$ \\
\hline Cucumber fruit & 95.3 & 87.1 \\
Cucumber leaf & 86.5 & 76.8 \\
Cucumber stem & 90.0 & 71.5 \\
Tomato fruit & 64.6 & 68.8 \\
Tomato leaf & 85.4 & 77.1 \\
Tomato stem & 64.6 & 58.0 \\
Paprika fruit & 70.8 & 91.1 \\
Paprika leaf & 87.3 & 79.3 \\
Paprika stem & 54.0 & 48.2 \\
Adlay straw & 81.7 & 81.5 \\
Chinese cabbage & 84.4 & 81.2 \\
Radish & 57.7 & 44.0 \\
Apple sludge & 95.9 & 89.3 \\
Pear sludge & 36.0 & 30.8 \\
Tangerine peel & 55.9 & 55.3 \\
White paper sludge & 92.0 & 47.2 \\
Yellow paper sludge & 67.0 & 40.3 \\
\hline
\end{tabular}

${ }^{\dagger}$ Ultimate methane potential / theoretical methane potential, ${ }^{\ddagger}$ VDI4630 method.

하기 까지는 매우 긴 시간을 요구하기 때문인 것으로 판단 되었다 (Li and Noike, 1992).

이론적 메탄생산퍼텐셜 대비 실험적 메탄생산퍼텐셜의 비율 $\left(\mathrm{B}_{\mathrm{u}} / \mathrm{B}_{\mathrm{th}}\right)$ 은 바이오가스 중의 메탄생산효율을 유기물의 분해율로 간주하는 방법이다. 이 방법은 실질적인 유기물의 분해산물이 다양한 구성성분을 포함하는 바이오 가스라는 점에서 오차를 유발할 가능성이 크다고 알려져 왔다 (Kim et al., 2012). 특히, 유기물의 메탄생산량과 이산화탄소 생 산량은 기질의 원소구성 특성에 영향을 받게 되며, 일반적 인 바이오가스 구성은 평균적으로 메탄 $60 \%$, 이산화탄소 $30 \%$ 로 구성되고 있으나 기질의 화학적 특성에 따라 메탄과 이 산화탄소의 비중은 언제든지 변동 될 수가 있다. 그리고 메 탄과 이산화탄소 외에도 기타 가스류 (암모니아, 황화수소 등)의 비중이 일반적으로 $10 \%$ 내외를 차지하게 된다. 그러나 일반으로 기타 가스도 기질의 특성에 따라 언제든지 그 양 은 변동이 있을 수 있다. 그러나 기존의 방법인 이론적 메탄 생산퍼텐셜 대비 실험적 메탄생산퍼텐셜 비율법은 단지 메 탄의 생산량만을 고려하여 그 분해율을 산정하고 있으며, 이산화탄소와 기타 가스는 전혀 고려하고 있지 않다. 본 연 구와 같이 주로 셀룰로오스계 바이오매스는 큰 영향이 없을 수 있겠으나 질소 성분이 다량 함유된 동물성 바이오매스의 경우는 암모니아 발생량이 상대적으로 커서 기타가스의 비
중이 늘어나게 된다. 그 외에도 해외에서는 유기물의 분해 시 미생물 바이오매스 증체를 $7 \%$ 가량 고려하고 있으나 $\mathrm{B}_{\mathrm{u}} / \mathrm{B}_{\mathrm{th}}$ 법은 미생물 증체량은 전혀 고려하고 있지 않아 전통적인 이 분해율 계산법이 간편하긴 하나, 그 정확도에 대해서는 의문이 들지 않을 수가 없다. 따라서 메탄생산율을 유기물 의 혐기적 분해율로 간주하는 것은 유기물간의 상대적인 분 해율 비교를 위해서만 가능할 것으로 생각되며, 유기물에서 기인하는 바이오가스 $\left(\mathrm{CH}_{4}, \mathrm{CO}_{2}\right.$, 기타가스)의 양을 기초로 하 며, 유기물의 바이오매스 증체량을 고려한 독일의 VDI4630법 의 정확도가 더 높을 것으로 판단된다.

\section{References}

Angelidaki, I., M. Alves, D. Bolzonella, L. Borzacconi, J.L. Campos, A.J. Guwt, S. Kalyuzhnyi, P. Jenicek, and J.B. vanLier. 2009. Defining the biomethane potential(BMP) of solid organic wastes and energy crops: a proposed protocol for batch assays. Water Sci. Technol. 59(5):927-934.

APHA. 1998. Standard methods for the examination of water and wastewater, 20th ed.

ASTM. 2008. E2170-01 Standard test method for determining the anaerobic biodegradation potential of organic chemicals. American Society for Testing and Materials. West Conshohocken, PA.

Beuvink, J.M., S.F. Spoelstra, and R.J. Hogendrop. 1992. An automated method for measuring the time course of gas production of feedstuffs incubated with buffered rumen fluid. Neth. J. Agri. Sci. 40:401-407.

Boyle, W.C. 1976. Energy recovery from sanitary landfills-a review. In: Schlegel, H.G., and, J., Barnea (Eds.), Microbial Energy Conversion. Pergamon Press Oxford, 119-138.

Buffiere, P., D. Loisel, N. Bernet, and J.P. Delgenes. 2006. Towards new indicators for the prediction of solid waste anaerobic digestion properties. Water Science \& Technology. Vol. 53, No. 8:233-241.

Gunaseelan, V.N. 1997. Anaerobic digestion of biomass for methane production: A review. Biomass and Bioenergy. Vol. 13. No. 1/2:83-114.

Kim, S.H., H. Kim, S.Y. Oh, C.H. Kim, and Y.M. Yoon. 2012. Effect of substrate to inoculum ratio on biochemical methane potential in the thermal pretreatment of piggery sludge. Korean J. soil Sci. Fert. 45(4):532-539.

Kim, S.H., H.C. Kim, C.H. Kim, and Y.M. Yoon. 2010. The measurement of biochemical methane potential in the several organic waste resources. Korean J. soil Sci. Fert. 43(3): 356-362.

Li, Y.Y. and T. Noike. 1992. Upgrading of anaerobic digestion of waste activated sludge by thermal pretreatment. Water Sci. Technol. 26:857-866.

Owen, W.F., D.C. Stuckey, J.B. Healy, L.Y. Young, and P.L. MaCarty. 1979. Bioassay for monitoring biochemical methane 
potential and anaerobic toxicity. Water Res. 12:485-492.

Shelton, D.R. and J.M. Tiedje. 1984. General method for determining anaerobic biodegradation potential. Appl. \& Environ. Microbiol. 47:850-857.

Shin, K.S., C.H. Kim, S.E. Lee, and Y.M. Yoon. 2011. Biochemical Methane Potential of Agricultural Waste Biomass. Korean J. soil Sci. Fert. 44(5):903-915.

Sorensen, A.H., M. Winther-Nielsen, and B.K. Ahring. 1991. Kinetics of lactate, acetate and propionate in unadapted and lactate-adapted thermophilic, anaerobic sewage sludge: the influence of sludge adaptation for start-up of thermophilic UASB-reactors. Micro biol. biotechnol. 34:823-827.

VDI 4630. 2006. Fermentation of organic materials, characterisation of the substrates, sampling, collection of material data, fementation test. VDI-Handbuch Energietechnik.

Williams, A., M. Amat-Marco, and M.D. Collins. 1996. Pylogenetic analysis of Butyrivibrio strains reveals three distinct groups of species within the Clostridium subphylm of gram-positive bacteria. Int. J. Syst. Bacterol. 46:195-199. 